\title{
Late Correction of Orbital Deformities Using Customized 3D Implant
}

\author{
Corrección Tardía de Deformidades de Órbita Usando Implantes Personalizados 3D
}

Felipe Martinez ${ }^{1,2}$; Juan Pablo Alister ${ }^{1,2,3}$; Francisca Uribe ${ }^{1,2,3} \&$ Sergio Olate $^{1,3,4}$

\begin{abstract}
MARTINEZ, F.; ALISTER, J. P.; URIBE, F.; OLATE, S. Late correction of orbital deformities using customized implant. Int. J. Morphol., 39(6):1683-1687, 2021.

SUMMARY: Late orbital reconstruction is a complex and challenge for surgeons. The aim of this article is to present complex orbital reconstruction using patient specific implant (PSI) strategy and polyetheretherketone (PEEK). A literature review and a cases series of sequelae after complex orbital trauma are presented; cases with great middle third deformities showing defect in the maxilla, nasal area, body of the zygoma and zygomatic arch were included; in both cases the sequelae was for more than 10 years. Virtual planning and PEEK implants were manufacture using a puzzle (two or three parts) by 3D print or injection. Patients were treated and their surgeries carried out without complications, using a minimal surgical approach. No infections were observed, and after 12 months follow-up they were stable showing normal function. PSI based-PEEK for orbital reconstruction are safe, efficient, effective and to obtain orbital morphology with low complications.
\end{abstract}

KEY WORDS: 3D implant; PSI; Orbital reconstruction; PEEK.

\section{INTRODUCTION}

Late surgery of the orbit is a complex challenge in maxillofacial surgery because the deformity is related to surgical difficulties and aesthetic requirements (Palmieri \& Ghali, 2012). Late orbital reconstruction is performed to treat complex trauma with no early surgery, or to treat complex or bad treatment (Palmieri \& Galhi). Sequelae in the orbital complex include bone repair related to bad union or nonunion; scar contractions and remodelling of soft tissues is present, which makes the correction more difficult (Gellrich et al., 2019).

Recovering morphology and function involves complex planning and adaptation strategies, and the use of materials to obtain full recovery with low morbidity; different materials for facial implants have been produced and adapted in the last years; on other hand, 3D assistance became popular in the 1990s and were quickly incorporated into facial surgery (Mankovich et al., 1990; Binder \& Kaye, 1994). Nowadays, a synergy between materials and 3D assistance is confirmed to treat difficult cases.
The aim of this article is to present the clinical application of Polyetheretherketone (PEEK) in complex reconstructions of the middle third face and orbit using 3D planning strategies and patient specific implant (PSI).

\section{CASE REPORTS}

Case 1. Female patient, aged 64 years, was referred to the Maxillofacial Surgery Unit to treatment of sequelae of orbital trauma after 13 years. Left orbital volume $40 \%$ greater than the right orbital volume was defined by computed tomography $(\mathrm{CT})$. A new cranium was designed by mirror image, and the model was used for recovery of orbital volume and facial contours, including sagittal projection of the zygomatic bone using PEEK.

Implant modelling was performed by PEEK injection into a negative model created from a 3D design, using a

\footnotetext{
${ }^{1}$ Division of Oral, Facial and Maxillofacial Surgery, University of La Frontera, Temuco, Chile.

${ }^{2}$ Department of Oral and Maxillofacial Surgery, HHA Hospital, Temuco, Chile.

${ }^{3}$ Center of Excellence in Morphological and Surgical Studies (CEMYQ), University of La Frontera, Temuco, Chile.

${ }^{4}$ Department of Oral and Maxillofacial Surgery, AGP Hospital, Temuco, Chile.
} 
software to model the shape and size of the implant. A dual PSI system with a puzzle strategy was designed using an extended transconjunctival approach and lateral canthotomy; the implant was fixed with plates on the upper area and screws in the body of the zygoma. The CT shows implant stability, symmetry and volume obtained similar to the right orbit (Fig 1).

Case 2. A 62-years-old male patient was referred to the Maxillofacial Surgery Unit with a complaint of orbito- zygomatic sequelae after 25 year related to a large maxillofacial trauma. The clinical diagnosis showed deformity of the orbit, maxilla, paranasal area and zygomatic arch.

After review, was decided the reconstruction with no modification of the sequel to modified volume over the defect; the poor quality of the soft tissue, long time scar, low vascular supply and another variable related to the patient, surgical time and anesthesia, was important for the clinical decision.
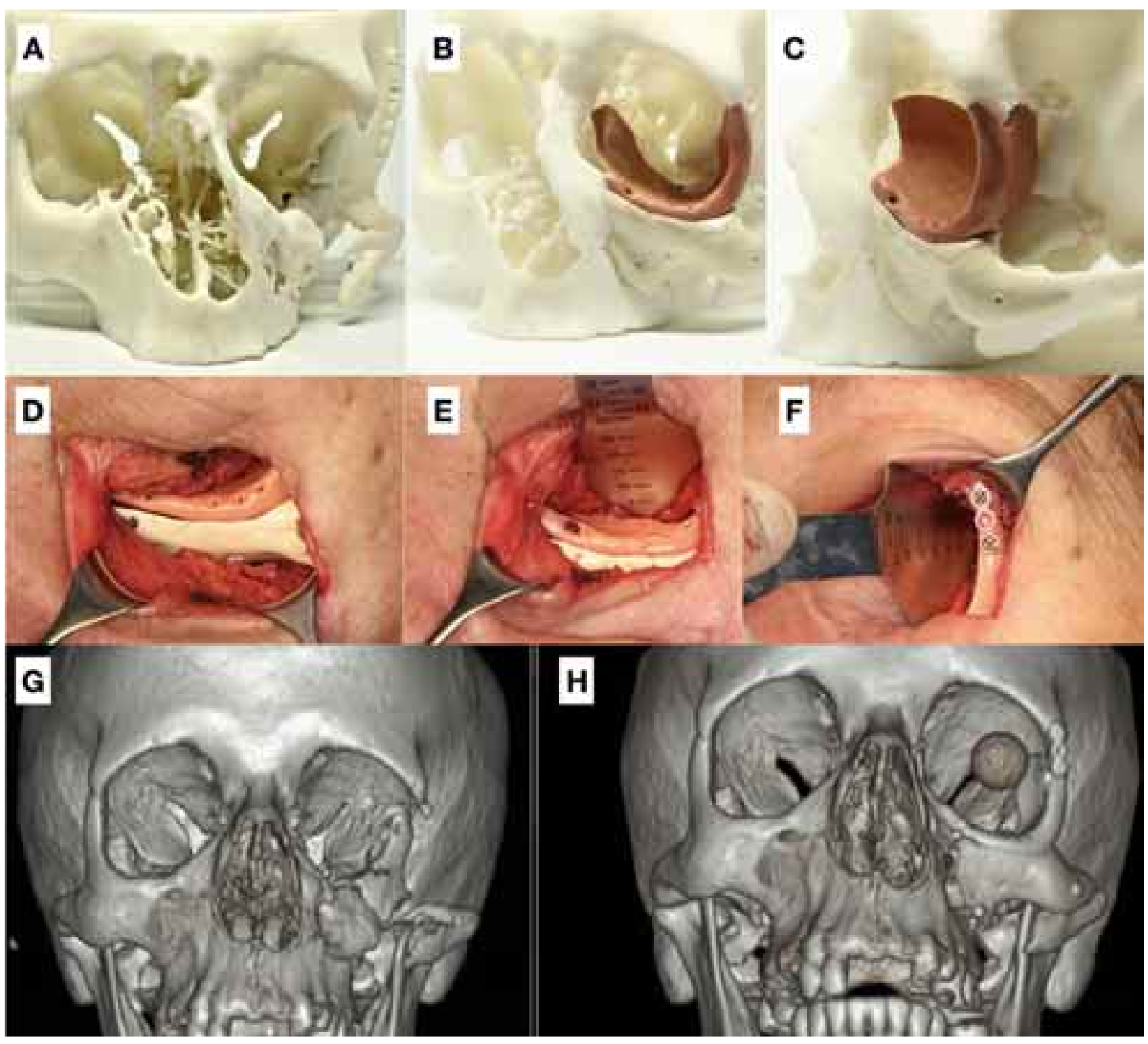

Fig. 1. A) An extensive destruction of the left middle third (case1). Was lost the facial integrity in this patient; was realized a biomodel and planned a PEEK implant by injection; B) orbital implant including zygoma and medial area of the orbit; C) lateral view showing the new lateral wall conformed by the implant; D) Transconjunctival approach to install the puzzle; E) Fixation of the implant in one point in the orbit; F) lateral view showing the proximity, fit and fixation on the frontal bone; G) Preoperative tomography showing the loss of structure and $\mathrm{H}$ ) Reconstruction of the orbital and zygoma complex by puzzle PSI. 
Recovery of shape, volume and size was planned using a PEEK implant with a puzzle technique. The 3D design of the implant was made and the manufacturing process involved 3D printing of PEEK (different to the first case realized by injection); the surgical approach by transconjunctival, intraoral and pre-auricular technique was used and fixation was made with screws on the bone. The CT shows the implant after installation, without complications and with proper assembly, following morphological planning of this reconstruction (Fig 2).
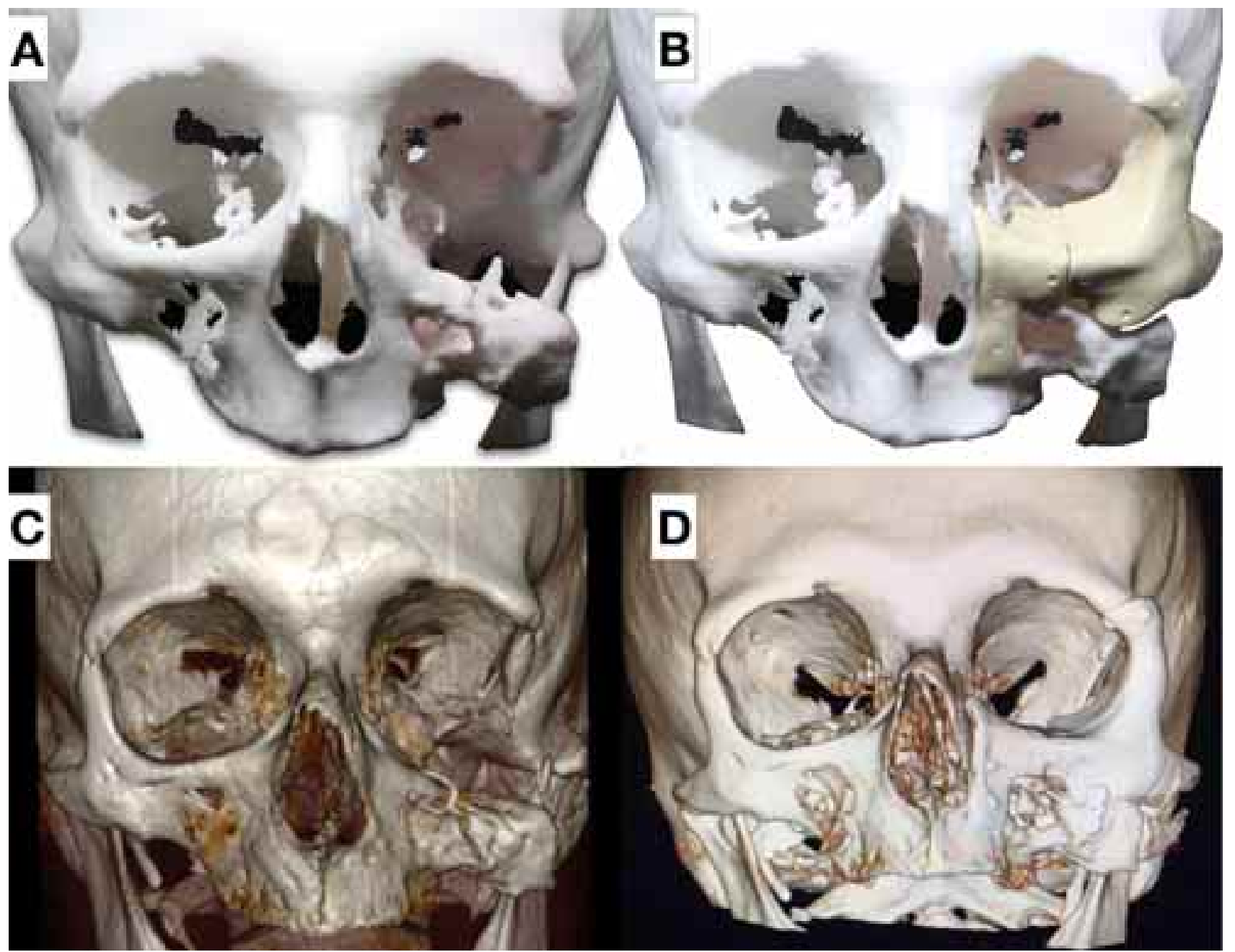

Fig. 2. A) Great loss of hard tissue is observed in the left orbit of this patient (case 2); B) biomodel was created from the computed tomography including zygomatic arch and maxilla; C) PEEK PSI was designed by puzzle application in a 3D print. Surgery was done with no complications and the implant was installed over the defect; D) CT showing good performance in final position and symmetry in the final position.

\section{DISCUSSION}

The use of PSI provides surgeons and patients advantages, such as safe planning and execution, especially in cases of facial asymmetries and complex facial defects (Patel et al., 2017). Disadvantages involved the requirements of high quality CT, increased planning time and increased economical cost (Binder \& Kaye). However, reduction in surgical time, precision in the technique and the low "re- entry surgery" are great advantages of this technology, and could show a reduction in long-term economic cost.

Currently, stock or customised implants and a wide range of manufacture materials are available. In 1994, Binder and Kaye (Binder \& Kaye) showed first reports of 3D assistance for implant planning and manufacture, with 
Table I. Summary of published cases using 3D print PEEK-based for orbital reconstruction.

\begin{tabular}{|c|c|c|c|}
\hline Authors & cases & Reconst ruction & Complications \\
\hline Alonso-Rodriguez et al. (2015) & 7 & $\begin{array}{l}\text { Orbit and Zygomaticomaxillary } \\
\text { complex }\end{array}$ & $\begin{array}{l}2 \mathrm{c} \text { ases with infection and } 1 \text { ca se } \\
\text { with replaced of the implant }\end{array}$ \\
\hline Saporano et al. (220) & 7 & Fronto-orbital & No \\
\hline Järvien et al. (2019) & 5 & Orbit & No \\
\hline Chepurnyi et al. (2020) & 28 & Orbital floor & No \\
\hline Gerbino et al. (2015) & 6 & $\begin{array}{l}\text { Orbit and Zygomaticmaxillary } \\
\text { complex }\end{array}$ & No \\
\hline
\end{tabular}

potential and effectiveness; designs based on 3D technology have been studied with high support and great results.

The materials available for these cases have been described extensively, considering autogenous bone and solid alloplastic materials (Potter et al., 2012). Polyetheretherketone (PEEK) is a highly resistant material with an elasticity module similar to bone. In these cases, PEEK injection into a threedimensional model created by $\mathrm{CAD} / \mathrm{CAM}$ allows adaptation to the surgical environment.

PEEK has been used for more than 30 years (William \& McNamara 1987), becoming - along with titanium - a good choice for these applications. Unlike titanium, PEEK offers the possibility of modification during surgery. This is important when complications from surgery are possible, such as incorrect osteotomies or other changes in the surgical room. PEEK can be ground, filed and modified, which titanium cannot. Other advantages of PEEK include the light weight of the implant, better viewing in image and the absence of artefacts in CT and MR.

PEEK is used in trauma, orthopaedic and spinal surgery, showing versatility in the process (Kurtz \& Devine, 2007). In the case of orbital reconstruction, the airflow and the biofilm from the maxillary sinus or nasal cavity could explain potential infections (Table I); however, postoperative infection is low and controlled, close to other types of implant, with high stability in primary and secondary reconstructions (Alonso-Rodriguez et al., 2015; Gerbino et al., 2015). This technique has been presented in other reports, showing that the puzzle format is useful in to reduce the size of the implants and minimize the surgical approach (Goodson et al., 2012).

It has been confirmed that PSI are more precise than stock units for orbital floor reconstruction (Zimmer et al., 2016); although the position and mobility of the eyeball showed no significant differences between groups using stock or PSI, the customised units required less surgical time (approx. $15 \%$ less). As well, Kand et al. (2020) indicated that virtual planning and the use of customised implants improved facial symmetry.
Our two cases were both highly complex, involving reconstruction of the middle third of the face, including extensive areas in the zygomatic bone, maxilla and zygomatic arch. The techniques used for modelling and manufacture, as well as the puzzle technique for intraoperative assembly, allowed better control in surgical approach, low morbidity and high predictability; no complications were observed in the surgery or in the followup time.

Recently has been presented 7 cases of unilateral fronto-orbital reconstruction using PEEK (Soporano et al., 2020); they obtained symmetry with differences of approximately $1.5 \mathrm{~mm}$, with no complications and no requirement for intraoperative modifications. Järvien et al. (2019) presented 24 cases using PEEK, of which 5 needed additional manipulation, with no infections in the followup. Our cases are in the same route, using puzzle technique with PEEK by injection or 3D printing, being versatile in both approaches.

Evidence in this field shows the good performance of PSI in facial reconstruction (Chepurnyi et al., 2020). However, clinical trials are necessary to confirm the key factors involved in this technique. Limitations in our report are related to a low sample and short follow-up; the authors could confirm that customised PEEK implants for orbital reconstruction are safe, efficient and effective; they show a versatile strategy for complex orbital reconstruction.

MARTINEZ, F.; ALISTER, J. P.; URIBE, F.; OLATE, S. Corrección Tardía de Deformidades de Orbita Usando Implantes Personalizados. Int. J. Morphol., 39(6):1683-1687, 2021.

RESUMEN: La reconstrucción tardía de la órbita es un desafío complejo para cirujanos. El objetivo de este artículo fue presentar la reconstrucción orbitaria compleja utilizando implante paciente específico (PSI) y polietereterketona (PEEK). Son presentados una revisión de literatura y una serie de casos con secuelas posteriores a un trauma orbitario complejo; además, son presentados casos con gran deformidad del tercio medio del rostro mostrando defectos en maxila, área nasal, cuerpo del hueso 
cigomático y arco cigomático; ambos casos de secuela fueron por más de 10 años. Planificación virtual e implantes en PEEK fueron creados usando una estrategia de puzzle (dos o tres partes) por inyección o impresión 3D. Los pacientes fueron tratados y sus cirugías realizadas sin complicaciones usando accesos quirúrgicos reducidos. No se observaron infecciones y después de 12 meses de seguimiento permanecieron estables mostrando función normal. Los PSI para reconstrucción orbitaria son seguros, eficientes, efectivos y recuperan morfología de órbita con bajas complicaciones.

\section{PALABRAS CLAVE: Implantes 3D; PSI; Reconstruc- ción de órbita; PEEK.}

\section{REFERENCES}

Alonso-Rodriguez, E.; Cebrian, J.L.; Nieto, M.J.; Del Castillo, J.L.; Hernández-Godoy, J. \& Burgueño, M. Polyetheretherketone custommade implants for craniofacial defects: report of 14 cases. $J$. Craniomaxillofac. Surg., 43:1232-8, 2015.

Binder, W.J. \& Kaye, A. Reconstruction of posttraumatic and congenital facial deformities with three dimensional computer-assisted custom designed implants. Plast. Reconstruc. Surg., 94:775-85, 1994.

Chepurnyi, Y.; Chernogorskyi, D.; Kopchak, A. \& Petrenko, O. Clinical efficacy of peek patient-specific implants in orbital reconstruction. $J$. Oral Biol. Craniofac. Res., 10:49-53, 2020.

Gellrich, N.C.; Dittmann, J.; Spalthoff, S.; Jehn, P.; Tavasso,1 F. \& Zimmerer, R. Current strategies in post-traumatic orbital reconstruction. $J$. Maxillofac. Oral Surg., 18:483-9, 2019.

Gerbino, G.; Zavattero, E.; Zenga, F.; Bianchi, F.A.; Garzino-Demo, P. \& Berrone, S. Primary and secondary reconstruction of complex craniofacial defects using polyetheretherketone custom-made implants. J. Craniomaxillofac. Surg., 43:135663, 2015.

Goodson, M.L.; Farr, D.; Keith, D. \& Banks, R.J. Use of two-piece polyetheretherketone (PEEK) implants in orbitozygomatic reconstruction. Br. J. Oral Maxillofac. Surg., 50:268-9, 2012.

Järvinen, S.; Suojanen, J.; Kormi, E.; Wilkman, T.; Kiukkonen, A.; Leikola, J. \& Stoor, P. The use of patient specific polyetheretherketone implants for reconstruction of maxillofacial deformities. J. Craniomaxillofac. Surg., 47:1072-6, 2019

Kand, Y.F.; Liang, J.; He, Z.; Zhang, L.; Shan, X.F. \& Cai, Z.G. Orbital floor symmetry after maxillectomy and orbital floor reconstruction with individual titanium mesh using computer-assisted navigation. J. Plast. Reconstr. Aesthetic. Surg., 73:337-43, 2020.

Kurtz, S.M. \& Devine, J.N. PEEK biomaterials in trauma, orthopaedic, and spinal implants. Biomaterials, 28:4845-9, 2007.

Mankovich, N.J.; Cheeseman, A.M. \& Stoker, N.G. The display of threedimensional anatomy with stereolithographic models. J. Dig. Imag., 3:200-3, 1990.

Palmieri, C.F. \& Ghali, G.E. Late correction of orbital deformities. Oral Maxillofac. Surg. Clin. N. Am., 24:649-63, 2012

Patel, N.; Kim, B. \& Zaid, W. Use of virtual surgical planning for simultaneous maxillofacial osteotomies and custom polyetheretherketone implant in secondary orbito-frontal reconstruction: importance of restoring orbital volume. J. Craniofac. Surg., 28:38790, 2017.

Polacco, M.A.; Kahng, P.W.; Sudoko, C.K. \& Gosselin, B.J. Orbital floor reconstruction: A comparison outcomes between absorbable and permanent implant systems. Craniomaxillofac. Trauma Reconstruc., 12:193-8, 2019.

Potter, J.; Malmquist, M. \& Ellis, III E. Biomaterial for reconstruction of the internal orbit. Oral Maxillofac. Surg. Clin. N. Am., 24:609-27, 2012.
Saporano, G.; Doneddu, P.; Gasparini, G.; Staderini, E.; Boniello, R.; Todaro, M.; D’Amato, G.; Pelo, S. \& Moro, A. Custom made onlay implants in peek in maxillofacial surgery. Child's Nerv Syst., 36:385-91, 2020.

Wu, J.; Shi, L.; Pei, Y.; Yang, D.; Gao, P.; Xiao, X.; Guo, S.; Li, M. \& Gou, Z. Comparative effectiveness of PEEK rods versus titanium alloys rods in cervical fusion in a new sheep model. Eur. Spine J., 29:1159-66, 2020.

William, D.F. \& McNamara, A. Potential of polyetheretherketone (PEEK) and carbon-fiber-reinforced PEEK in medical applications. J. Mater. Sci. Letter, 6:188-90, 1987.

Zimmer, R.M.; Ellis, III E.; Sanchez Ancieto, G.; Schramm, A.; Wagner, M.; Grant, M.P.; Cornelius, C.P.; Strong, E.; Rana, M. et al. A prospective multicenter study to compare the precision of posttraumetic internal orbital reconstruction with standard performed and individualized orbital implants. J. Craniomaxillofac. Surg., 44:148597, 2016

\section{Correspondence author:}

Sergio Olate, DDS, PhD

Centro de Excelencia en Estudios Morfológicos y Quirúrgicos Universidad de La Frontera

Temuco

CHILE

\section{E-mail: sergio.olate@ufrontera.cl}

Received: 09-08-2021

Accepted: 16-09-2021 